\title{
Primary Testicular Diffuse Large B-cell Lymphoma: A Rare Case Report
}

\author{
(D) Mustafa Ozan Horsanalı1, (D) Gürol Akan2, (D) Saniye Sevim Tuncer3 \\ 1 Izzmir Bakırçay University Faculty of Medicine, Department of Urology, İzmir, Turkiye \\ 2Izmir Bakırçay University Çiğli Training and Research Hospital, Clinic of Urology, İzmir, Turkiye \\ 3izmir Bakırçay University Çiğli Training and Research Hospital, Clinic of Pathology, Izmir, Turkiye
}

\begin{abstract}
A 53-year-old male patient was admitted with a right testicular solid and painless mass at our clinic. A solid, irregular, $6 \times 6 \mathrm{~cm}$ sized mass was palpated on physical examination. Serum tumor markers were within normal range and a scrotal Doppler ultrasonography revealed a hypoechogenic, hypervascular, $69 \times 35 \mathrm{~mm}$ sized mass on the right testis. No metastasis was found on the non-contrast-enhanced thoracoabdominal tomography. Right inguinal orchiectomy was performed. A diagnosis of testicular diffuse large B-cell lymphoma was made based on the pathological evaluation. The patient consulted with the hematology department and followed up. During the follow-up, no metastasis was observed.
\end{abstract}

Keywords: Testis, lymphoma, B-cell, orchiectomy, chemotherapy

\section{Introduction}

Testicular lymphoma is a rare malignancy among urogenital malignancies. It constitutes 5-9\% of testicular tumors, 2\% of extranodal lymphomas, and 1-2\% of non-Hodgkin lymphomas. Generally, it appears as an aggressive tumor in an advanced stage. Approximately $80 \%$ of patients have diffuse large B-cell lymphoma as the histopathological type of primary testicular lymphoma (1). Diffuse large B-cell lymphoma is often observed in male patients aged 60 years and over (2). Median survival time was reported as 4.6 years in a study (3). Remission may occur with combined treatment, but extranodal relapse is frequently observed (4). This study aimed to present a case with primary testicular diffuse large B-cell lymphoma.

\section{Case Report}

A 53-year-old male patient was admitted at our clinic with a complaint of painless, solid, scrotal swelling for approximately 25 days. On physical examination, a solid, irregular, painless mass with a size of $6 \times 6 \times 6 \mathrm{~cm}$ was palpated on the right testis, with an intact spermatic cord. Patient history revealed no comorbid diseases and he is a smoker. Laboratory evaluation revealed serum tumor markers of $\beta$-human chorionic gonadotropin $<0.1 \mathrm{IU} / \mathrm{mL}$, alpha-fetoprotein $=2.3 \mathrm{ng} / \mathrm{mL}$, lactate dehydrogenase $=158 \mathrm{IU} / \mathrm{L}$, and other laboratory parameters within normal limits. Scrotal colored Doppler ultrasonography was performed to determine the characteristic of the testicular mass for radiological evaluation. Any pathological image was not observed on the left testis; however, a $69 \times 35 \mathrm{~mm}$ in size hypoechogenic structured mass with increased vascularization was found on the right testis. Non-contrast enhanced thoracoabdominal tomography was performed to evaluate the existence of metastasis, which revealed no metastasis. After obtaining the patient's consent, right inguinal orchiectomy was performed with the diagnosis of a right testicular tumor according to these findings.

\section{Pathological Evaluation}

Macroscopic examination: The surgical resection material contained $6.5 \times 4.5 \times 4.5 \mathrm{~cm}$ sized testis and $6.5 \times 1.5 \mathrm{~cm}$ sized spermatic cord. On the testicular side, a solid-structured mass formation with a size of $6 \times 6 \times 5 \mathrm{~cm}$ was observed. Areas of bleeding were shown in yellow-white color (Figure 1).

Microscopic examination: Medium-large-sized diffuse neoplastic cell infiltration with a high mitotic index was observed (Figure 2B).

Correspondence: Mustafa Ozan Horsanalı MD, İzmir Bakırçay University Faculty of Medicine, Department of Urology, i̇zmir, Turkiye Phone: +90 5079942217 E-mail: drozanhorsanali@yahoo.com ORCID-ID: orcid.org/0000-0002-3651-0948 Received: 16.01 .2021 Accepted: 21.02 .2021

Cite this article as: Horsanalı MO, Akan G, Tuncer SS. Primary Testicular Diffuse Large B-cell Lymphoma: A Rare Case Report. J Urol Surg 2021;8(3):220-222.

${ }^{\circ}$ Copyright 2021 by the Association of Urological Surgery / Journal of Urological Surgery published by Galenos Publishing House. 
Immunohistochemical examination: In the immunohistochemical staining of neoplastic cells, focal involvement was observed for multiple myeloma oncogene (MUM)-1, cluster of differentiation (CD) 43, CD5, and CD10. Positive staining was observed for paired box 5, CD79, and CD20. In addition, approximately 40\% positive staining for $\mathrm{C}-$ myc and $>70 \%$ positive staining for $\mathrm{Bcl}-2$ were observed. Coexpression of CD10 and MUM-1 is observed, and the case with a high Ki-67 proliferation index was diagnosed as diffuse large B-cell lymphoma due to the C-myc detection as well as Bcl-2 positivity although classification is not made according to the Hans algorithm (Figure 2).

The patient consulted with the hematology specialist after surgical treatment. The patient was diagnosed with primary testicular lymphoma and started chemotherapy since other primary lymphoma sources were not detected. No signs of

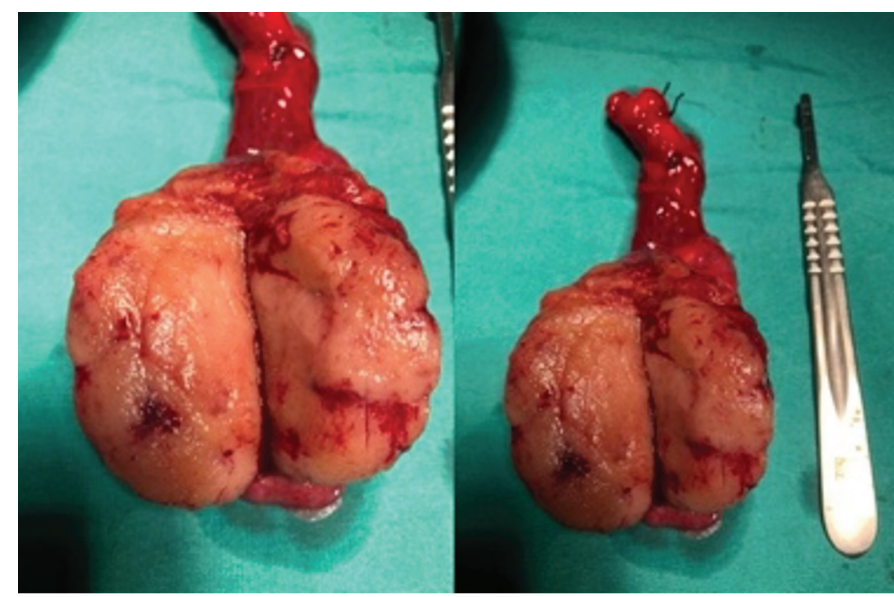

Figure 1. Macroscopic image of a surgical specimen

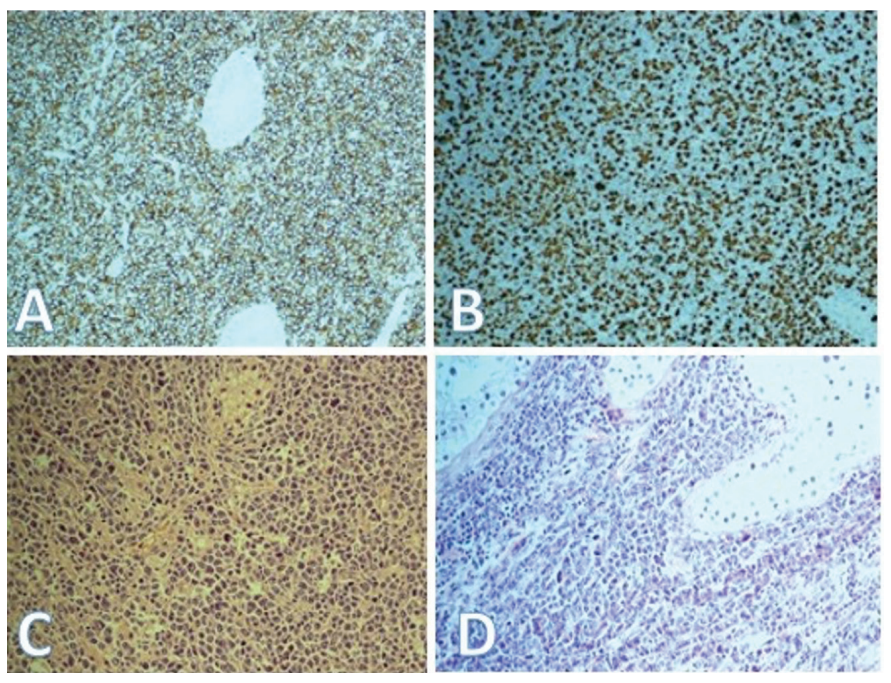

Figure 2. Microscopic and immunohistochemical images of a specimen A) CD45 positivity in atypical lymphoid cells, CD45-10X, B) Nuclear Ki-67 positivity showing high cardio-mitotic index in atypical lymphoid cells, Ki67-10X, C) Infiltration of medium-large atypical lymphocytes with nucleolus prominence, H\&E-10X, D) Medium-large sized atypical lymphoid cells infiltrating testicular parenchyma, HCtE-10X relapse or metastasis were observed in the postoperative $6^{\text {th }}$ month follow-up of the patient.

\section{Discussion}

This case report aimed to present a patient with a rare testicular mass diagnosed with diffuse large B-cell lymphoma, which is generally observed after the $6^{\text {th }}$ decade.

Extranodal localization of testicular B-cell lymphoma increased the risk of relapse and tumor aggressiveness (5). Germinal center B-cell is defined according to the immunohistochemical evaluation and characterized with positive staining of MUM-1, CD10, and Bcl-6 (6). In the study of Pătraşcu et al. (7), Bcl-2 positivity was reported as common in the range of approximately $50 \%$. Our patient had MUM-1, CD10, and Bcl-2 positive staining in the immunohistochemical evaluation.

No consensus about the treatment of primary testicular diffuse B-cell lymphoma was made. Despite the recent treatment developments, the prognosis is often poor (6). Relapse risk is high due to the lack of standard treatment for primary testicular diffuse large cell lymphoma. Recommended therapy is a combination of surgery and chemotherapy especially for central nervous system relapse due to high relapse risk. Additionally, radiotherapy with 30 Gy to the contralateral testis for patients with high relapse risk is recommended $(5,8)$. A 5-year survival rate may increase from 30\% to $86.6 \%$ with multimodal therapy (9). In our case, combined therapy including surgery and chemotherapy was performed and no relapse was observed. Radiotherapy was not performed.

\section{Conclusion}

Primary testicular lymphoma is a rare type of extranodal lymphoma, but it can be difficult to treat with reduced survival if diagnosed late. Early diagnosis and initiation of combined therapy including surgery, chemotherapy, and radiotherapy at the contralateral testis is the only curative therapy in these patients.

\section{Ethics}

Informed Consent: Informed consent was obtained.

Peer-review: Externally peer-reviewed.

\section{Authorship Contributions}

Surgical and Medical Practices: G.A., Concept: M.O.H., Design: M.O.H., S.S.T., Data Collection or Processing: M.O.H., G.A., S.S.T., Literature Search: M.O.H., G.A., S.S.T., Writing: M.O.H., S.S.T.

Conflict of Interest: No conflict of interest was declared by the authors. 
Financial Disclosure: The authors declared that this study received no financial support.

\section{References}

1. Møller MB, d'Amore F, Christensen BE. Testicular lymphoma: a populationbased study of incidence, clinicopathological correlations and prognosis. The Danish Lymphoma Study Group, LYFO. Eur J Cancer 1994;30A:17601764.

2. Vitolo U, Ferreri AJ, Zucca E. Primary testicular lymphoma. Crit Rev Oncol Hematol 2008;65:183-189.

3. Gundrum JD, Mathiason MA, Moore DB, Go RS. Primary testicular diffuse large B-cell lymphoma: a population-based study on the incidence, natural history, and survival comparison with primary nodal counterpart before and after the introduction of rituximab. J Clin Oncol 2009;27:5227-5232.

4. Zucca E, Conconi A, Mughal TI, Sarris AH, Seymour JF, Vitolo U, Klasa R, Ozsahin M, Mead GM, Gianni MA, Cortelazzo S, Ferreri AJ, Ambrosetti A, Martelli M, Thiéblemont C, Moreno HG, Pinotti G, Martinelli G, Mozzana R, Grisanti S, Provencio M, Balzarotti M, Laveder F, Oltean G, Callea V, Roy $\mathrm{P}$, Cavalli $\mathrm{F}$, Gospodarowicz MK; International Extranodal Lymphoma Study Group. Patterns of outcome and prognostic factors in primary large- cell lymphoma of the testis in a survey by the International Extranodal Lymphoma Study Group. J Clin Oncol 2003;21:20-27.

5. Rotaru I, Nacea JG, Foarfă MC, Ciovică DV, Pătraşcu AM. Primary diffuse large B-cell lymphoma of the testis. Rom J Morphol Embryol 2018;59:585589.

6. Mlika M, Chelly I, Benrhouma M, Haouet S, Horchani A, Zitouna MM, Kchir N. A Primary Testicular Diffuse Large B-cell Lymphoma Belonging to the Germinal Center B-cell-like Group. J Clin Med Res 2010;2:47-49.

7. Pătraşcu AM, Rotaru I, Olar L, Pătraşcu Ş, Ghiluşi MC, NeamȚu SD, Nacea JG, Gluhovschi A. The prognostic role of Bcl-2, Ki67, c-MYC and p53 in diffuse large B-cell lymphoma. Rom J Morphol Embryol 2017;58:837-843.

8. Vitolo U, Chiappella A, Ferreri AJ, Martelli M, Baldi I, Balzarotti M, Bottelli C, Conconi A, Gomez H, Lopez-Guillermo A, Martinelli G, Merli F, Novero D, Orsucci L, Pavone V, Ricardi U, Storti S, Gospodarowicz MK, Cavalli F, Sarris AH, Zucca E. First-line treatment for primary testicular diffuse large B-cell lymphoma with rituximab-CHOP, CNS prophylaxis, and contralateral testis irradiation: final results of an international phase II trial. J Clin Oncol 2011;29:2766-2772.

9. Wang , Zheng D, Chai D, Wu S, Wang X, Chen S, Wu L, Cao R, Tao Y. Primary testicular diffuse large B-cell lymphoma: Case series. Medicine (Baltimore) 2020;99:e19463. 